\title{
HUBUNGAN TINGKAT PENGETAHUAN TENTANG KUSTA DENGAN KEPATUHAN MINUM MDT (MULTIDRUG THERAPY) PADA PASIEN KUSTA DI PUSKESMAS KEJAYAN DAN PUSKESMAS POHJENTREK KABUPATEN PASURUAN
}

\author{
Sutik Meru*, Sri Winarsih ${ }^{\star \star \bowtie}$, Tony Suharsono*
}

\begin{abstract}
Abstrak
Kusta merupakan penyakit kronis yang disebabkan Mycobacterium leprae yang menyerang kulit dan saraf tepi. Untuk menunjang keberhasilan program terapi kusta, pemerintah menggunakan rekomendasi WHO yaitu program MDT (Multidrug Therapy) selama 12 bulan. Penelitian ini berjenis deskriptif analitik observasional dengan desain croos sectional. Tujuan penelitian ini untuk mengetahui hubungan antara tingkat pengetahuan pasien kusta dengan kepatuhan minum MDT. Populasi yang digunakan adalah penderita kusta di wilayah kerja Puskesmas Kejayan dan Puskesmas Pohjentrek Kabupaten Pasuruan. Sampel diambil secara purposive sampling, yaitu penderita kusta yang masih aktif mengikuti program MDT dan penderita masa pengamatan yang memenuhi kriteria inklusi, berjumlah 41 orang. Data tingkat pengetahuan diperoleh melalui kuesioner, data kepatuhan diperoleh melalui lembar observasi yang dibantu petugas kusta. Hasil yang diperoleh dari tingkat pengetahuan pasien kusta dalam katagori tinggi $(70,7 \%)$, dengan kepatuhan dalam katagori patuh $(56,1 \%)$. Analisis bivariat dengan menggunakan chi square didapatkan koefisien kontigensi sebesar 6,667 dengan signifikansi $p$ value sebesar $0,025^{* *}(p<0,05)$. Dapat disimpulkan ada hubungan bermakna antara tingkat pengetahuan pasien kusta dengan kepatuhan minum MDT dengan hubungan keeratan rendah. Kepatuhan didukung oleh tingkat pengetahuan yang tinggi, petugas kesehatan yang profesional dan dukungan keluarga melalui peran serta masyarakat. Ketidakpatuhan lebih banyak terdapat pada aspek pengobatan.
\end{abstract}

Kata Kunci: kepatuhan, kusta, multidrug therapy, tingkat pengetahuan.

\section{THE CORRELATION OF KNOWLEDGE LEVEL ON LEPROSY WITH THE DRINKING OBEDIENCE OF MDT (MULTIDRUG THERAPY) IN LEPROSY PATIENTS AT PUBLIC HEALTH CENTER KEJAYAN AND PUBLIC HEALTH CENTER POHJENTREK PASURUAN}

\begin{abstract}
Leprosy is a chronic disease due to Mycobacterium leprae that infecting the skin and peripheral nerves. Indonesian government apply MDT (Multidrug Therapy) program for 12 months as a WHO recommendation on leprosy treatment. This research was descriptive analytic with cross sectional observasional design. The goal of the research was to find out the correlation between knowledge level on leprosy with obedience in taking MDT (Multidrug Therapy). The samples derived from leprosy patients in public health center in Kejayan and in Pohjentrek Pasuruan that were chosen by purposive sampling. They were still active leprosy following the MDT program, also in observation period who met the inclusion criteria, totaling 41 people. The data of level knowledge was obtained by using questionnaires, data obtained through observation that assisted leprosy officer. The result showed that the knowledge of leprosy patient was high $(70.7 \%)$, with compliance level was in the category of obedient $(56.1 \%)$. The result of chi square showed that contingency coefficient analysis of two variables was 6.667 with $p$ value was $0.025^{* *}(p<0.05)$. It is concluded there was a significant correlation knowledge level leprosy with obedience in applying MDT (Multidrug Therapy) but the association is weak. Obedience is supported by a high level of knowledge, health professional and family support through community participation. Disobedience is more prevalent on the aspects treatment.
\end{abstract}

Keywords: leprosy, level of knowledge, multidrug therapy, obedience

*Program Studi Ilmu Keperawatan, FKUB

*Lab Mikrobiologi, FKUB

凶wiensri238@gmail.com 


\section{Pendahuluan}

Penyakit kusta merupakan jenis penyakit kronis dan menular yang dapat menimbulkan kecacatan. Penyakit kusta tidak hanya menimbulkan masalah kesehatan melainkan juga masalah ekonomi, sosial, dan budaya bagi penderitanya terutama di negara-negara berkembang seperti Indonesia. Penyakit kusta dapat menyerang semua golongan umur dan terdapat perbedaan dalam hal ras maupun geografis. ${ }^{1}$

Salah satu program yang ditetapkan untuk mencapai tujuan dan sasaran pembangunan di bidang kesehatan adalah pencegahan dan pemberantasan penyakit menular. Penyakit menular yang masih menimbulkan masalah kesehatan masyarakat adalah penyakit kusta. ${ }^{2}$

Masalah kusta bukan hanya masalah kesehatan (medis) saja, tetapi juga masalah sosial ekonomi dan psikiologis. Secara sosial ekonomi penderita kusta sebagian besar adalah golongan ekonomi lemah, dengan adanya cacat akibat penyakit kusta akan memburuk kondisi ekonominya karena kehilangan lapangan pekerjaan dan kehilangan kesempatan untuk bekerja. Secara psikologis bercak dan benjolan-benjolan pada kulit penderita kusta membentuk paras yang menakutkan. Hal ini menyebabkan penderita kusta merasa rendah diri, depresi, menyendiri bahkan sering dikucilkan oleh keluarga maupun masyarakat sekitarnya. ${ }^{3}$

Penderita kusta tersebar di seluruh dunia, ada pendapat penyakit kusta berasal dari Asia Tengah kemudian menyebar ke Mesir, Eropa, Afrika dan Amerika. Indonesia merupakan negara ketiga terbanyak penderita kusta di bawah India dan Brazil dengan jumlah kasus 16.572.4 Berdasarkan Profil Kesehatan Propinsi Jawa Timur, Jawa Timur menempati urutan ke tujuh di antara provinsi lainya di Indonesia dengan jumlah penderita kusta terdaftar 6.833 dan angka prevalensi 1,83 per 10.000 penduduk. Sepertiga jumlah penderita kusta di Indonesia berada di Jawa Timur, penyebaran penyakit kusta di Jawa Timur terutama berada di pantai utara Pulau Jawa dan Pulau Madura. ${ }^{5}$ Melihat masalah di atas, kusta perlu mendapat perhatian serius sehingga penemuan dan pengobatan penderita sampai sembuh merupakan salah satu kunci pemberantasan kusta. Untuk mencapai kesembuhan penyakit kusta diperlukan keteraturan atau kepatuhan berobat bagi setiap penderita. Kendala pengobatan kusta yaitu kondisi ekonomi masyarakat dan bukti pasti menunjukan kepatuhan menjalani pengobatan masih rendah.

Tahun 2006 WHO mengeluarkan kebijakan Global Strategy for Further Reducing the Leprosy Burden and Suistaning Leprosy Control Activities (2006-2010) yaitu untuk menurunkan beban penyakit dan kesinambungan program pemberantasan penyakit kusta, dengan cara menurunkan angka kesakitan atau angka prevalensi kurang dari 1 per 10.000 penduduk, serta untuk mencapai eliminasi kusta masih diperlukan peningkatan kualitas program kegiatan yang meliputi penemuan penderita baru, pengobatan yang tepat dengan Multidrug Therapy (MDT), tingkat kepatuhan pengobatan dan pemantauan kasus, pencegahan cacat, rehabilitasi non medis atau sosial dan promosi kesehatan. Akhir tahun 2005 lebih dari $60 \%$ wilayah (17 propinsi dan 315 kabupaten/kota) sudah mencapai eliminasi. Pengobatan kusta merupakan Program Kementrian Kesehatan RI yang memerlukan waktu lama antara 6-12 bulan, serta memiliki resiko tentang ketidakpatuhan berobat dan mengkonsumsi obat. ${ }^{6}$

Berdasarkan Profil Kesehatan Kabupaten Pasuruan, pada tahun 2011 Kabupaten Pasuruan berada diurutan ke 11 daerah high prevalens dari 38 kabupaten/kota se-Jawa Timur, insiden di Kabupaten Pasuruan dengan jumlah penduduk 1.528.385 terdapat 371 kasus kusta terdaftar yang terbagi menjadi 304 penderita tipe MB dan 67 penderita tipe PB dan kasus berhenti berobat (drop out) 31 
penderita kusta, berarti angka kesakitan (prevalensi) 2,43 per 10.000 penduduk. Angka ini sangat tinggi dibandingkan target prevalensi kusta nasional. Berdasarkan data rekam medis penderita kusta di Puskesmas Kejayan pada bulan Desember 2011 terdapat 28 penderita kusta yang terbagi menjadi 24 penderita tipe $\mathrm{MB}$ dan 4 penderita tipe $\mathrm{PB}$, dan 7 penderita sudah berhenti mengambil obat MDT (drop out), serta data rekam medik penderita kusta di Puskesmas Pohjentrek berjumlah 23 penderita yang terbagi menjadi 19 penderita tipe MB dan 4 penderita tipe $\mathrm{PB}$, dan 3 penderita sudah berhenti mengambil obat MDT (drop out).

Angka prevalensi penderita kusta di Puskesmas Kejayan menempati urutan kelima, serta Puskesmas Pohjentrek menempati urutan kedelapan dari sebanyak 33 Puskesmas se-Kabupaten Pasuruan. Daerah endemis dan penyebaran pasien kusta di dua wilayah Puskesmas sudah tercatat. Penderita kusta sudah tahu tentang penyakitnya dan berobat, tetapi masih ada yang tidak patuh mengambil obat paket MDT. Penderita kusta yang sudah berobat, ada yang tidak mengambil obat MDT karena malas dan merasa sudah sembuh.

Ketaatan dan kepatuhan minum obat MDT pada penderita kusta dipengaruhi oleh lamanya masa pengobatan sehingga diperlukan keuletan dan ketekunan karena dapat menimbulkan rasa bosan, adanya perasaan sudah sembuh mengakibatkan penderita menghentikan pengobatan sebelum masa akhir pengobatan selesai. ${ }^{7}$

Keberhasilan suatu pengobatan ditentukan oleh kepatuhan dalam menjalankan terapi pengobatan. Berbagai faktor dapat mempengaruhi kepatuhan minum obat meliputi usia, jenis kelamin, status sosial ekonomi yang rendah, tingkat keparahan penyakit, golongan obat yang diresepkan, jumlah obat yang diminum, efek samping obat, pengetahuan tentang penyakit yang diderita dan pengetahuan mengenai pentingnya pengobatan. ${ }^{8}$
Penelitian ini dilakukan untuk mengetahui hubungan tingkat pengetahuan tentang kusta dengan kepatuhan minum MDT pada pasien kusta di Puskesmas Kejayan dan Puskesmas Pohjentrek Kabupaten Pasuruan, sehingga dapat digunakan sebagai dasar untuk menentukan kebijakan Pemerintah Kabupaten Pasuruan dalam rangka mensukseskan program eliminasi kusta dan target standar pelayanan minimal.

Manfaat penelitian dalam bidang akademis yaitu untuk pengembangan ilmu kesehatan khususnya tentang konsep kepatuhan minum MDT penderita kusta serta mendukung penelitian lain untuk mencari solusi pemecahan masalah yang lebih baik dalam mencapai tujuan terapi pasien kusta secara optimal.

Manfaat untuk praktek keperawatan hasil penelitian dapat digunakan untuk meningkatkan pemahaman tenaga kesehatan di Puskesmas Kejayan dan Puskesmas Pohjentrek tentang kepatuhan minum MDT penderita kusta sehingga dapat mengkaji dan memberikan intervensi lebih optimal pada pasien kusta yang tidak terkontrol dalam pengawasan minum obat.

\section{Bahan dan Metode}

Desain penelitian yang digunakan adalah analitik korelasi dengan pendekatan cross sectional. Teknik sampling yang digunakan dalam penelitian ini adalah dengan teknik nonprobability sampling secara purposive sampling. Cara pengambilan sampel menggunakan kriteria inklusi dan eksklusi. ${ }^{10}$ Populasi dalam penelitian ini adalah semua pasien yang didiagnosa menderita penyakit kusta dan mendapatkan program terapi MDT selama 12 bulan serta pasien kusta dalam masa pengamatan sampai 24 bulan di Puskesmas Kejayan Kabupaten Pasuruan dengan jumlah populasi sebanyak 28 orang yang didapatkan dari rekam medis penderita kusta di Puskesmas Kejayan, ditambah populasi sebanyak 23 orang yang didapatkan 
Meru S, et al.

dari rekam medis penderita kusta di Puskesmas Pohjentrek Kabupaten Pasuruan.

\section{Hasil}

\section{Gambaran Umum}

Puskesmas Kejayan merupakan salah satu Puskesmas yang terletak di wilayah Kabupaten Pasuruan Propinsi Jawa Timur. Luas wilayah kerja Puskesmas Kejayan 4513,162 Ha, terdiri dari 17 Desa, 63 Dusun, 98 RW dan 252 RT dengan jumlah penduduk 39.605 jiwa per Desember 2011. Batas wilayah kerja yaitu utara: Puskesmas Pohjentrek, selatan: Puskesmas Ambal-Ambil, timur: Puskesmas Gondang Wetan, barat: Kecamatan Kraton. Program pemberantasan penyakit kusta adalah salah satu program pendukung dalam menyelenggarakan pelayanan kesehatan di komunitas masyarakat serta untuk mensukseskan program pemerintah dalam rangka mencapai target MDGs 2015, khususnya pencegahan dan pemberantasan penyakit menular.

Puskesmas Pohjentrek juga merupakan salah satu Puskesmas yang terletak di wilayah Kabupaten Pasuruan Propinsi Jawa Timur.
Hubungan Tingkat Pengetahuan tentang Kusta

Luas wilayah kerja Puskesmas Pohjentrek 122,4 Ha, terdiri dari 9 Desa, 31 Dusun, 51 RW dan 170 RT dengan jumlah penduduk 29.367 jiwa per Desember 2011. Batas wilayah kerja yaitu utara: Kota Pasuruan, selatan: Puskesmas Kejayan, timur: Puskesmas Gondang Wetan, barat: Puskesmas Ngempit-Kraton.

Berdasarkan hasil pengumpulan data kuesioner tentang tingkat pengetahuan dan serangkaian observasi kepatuhan terhadap program terapi yang dilakukan di Puskesmas Kejayan dan Puskesmas Pohjentrek Kabupaten Pasuruan disajikan dalam bentuk analisis distribusi frekuensi univariat, gambar diagram dan analisis deskripsi bivariat dengan metode statistik menggunakan program SPSS.

\section{Distribusi Frekuensi Karakteristik Responden}

Hasil distribusi karakteristik pasien kusta di dua puskesmas yang bersedia mengiikuti proses penelitian dapat terlihat pada Tabel 1 berikut.

Tabel 1. Frekuensi karakteristik umur

\begin{tabular}{ccccc}
\hline Variabel & Mean & St.Deviasi & Min-Max & $95 \% \mathrm{Cl}$ \\
\hline Umur & 31.02 & 15.09 & $12-65$ & $26.26-35.78$
\end{tabular}

Pada Tabel 1 di atas, dapat diketahui rentang umur responden yang mengikuti program MDT di Puskesmas Kejayan dan Puskesmas Pohjentrek mayoritas dengan rentang usia termuda berumur 12 tahun dan usia tertua 65 tahun. Sementara pada Tabel 2, untuk jenis kelamin sebagian besar sampel yang mengikuti program MDTmayoritas lakilaki 26 orang $(63,4 \%)$, Pendidikan responden mayoritas menengah yaitu SLTP/MTS sebanyak 19 orang $(46,3 \%)$, status pekerjaan responden sebagian besar bekerja pada sektor informal/swasta sebanyak 22 orang $(53,7 \%)$. 
Tabel 2. Frekuensi jenis kelamin, pendidikan, dan pekerjaan pasien kusta

\begin{tabular}{lcc}
\hline \multicolumn{1}{c}{ Variabel } & $\mathrm{N}$ & Persentase (\%) \\
\hline Jenis Kelamin & & \\
\hline Laki-Laki & 26 & 63.4 \\
Perempuan & 15 & 36.6 \\
\hline Jumlah & 41 & 100.0 \\
\hline Tingkat Pendidikan & & \\
\hline SD & 18 & 43.9 \\
SLTP/MTS & 19 & 46.3 \\
SLTA & 4 & 9.8 \\
\hline Jumlah & 41 & 100.0 \\
\hline Pekerjaan & & 46.3 \\
\hline Petani & 19 & 53.7 \\
Swasta & 22 & 100.0 \\
\hline Jumlah & 41 & \\
\hline
\end{tabular}

\section{Distribusi Frekuensi Tingkat Pengetahuan} tentang Kusta dan Kepatuhan Minum MDT

Pada Tabel 3, diketahui bahwa mayoritas pasien kusta memiliki tingkat pengetahuan yang tinggi yaitu sebanyak 29 orang $(70,7 \%)$, dan hanya sebagian kecil responden yang memiliki tingkat pengetahuan sedang tentang pengobatan yaitu sebanyak 12 orang $(29,3 \%)$. Sebagian besar responden pasien kusta memiliki kepatuhan minum MDT yaitu sebanyak 23 orang $(56,1 \%)$, dan sebagian kecil responden yaitu 18 orang responden $(43,9 \%)$ yang tidak patuh minum MDT. Sebagian besar responden tidak patuh dalam aspek pengobatan meliputi: lupa minum obat, efek samping MDT yaitu Dapsone (pusing/mual), Lamprene (kulit tampak menghitam) dan Rifampisin (urine berwarna merah) di Puskesmas Kejayan dan Puskesmas Pohjentrek.

Tabel 3. Frekuensi tingkat pengetahuan tentang kusta dan kepatuhan minum MDT

\begin{tabular}{ccc}
\hline Variabel & Frekuensi & Persentase (\%) \\
\hline Tingkat Pengetahuan & & \\
\hline Sedang & 12 & 29,3 \\
Tinggi & 29 & 70,7 \\
\hline Jumlah & 41 & 100,0 \\
\hline Kepatuhan Minum MDT & & \\
\hline Tidak patuh & 18 & 43,9 \\
Patuh & 23 & 56,1 \\
\hline Jumlah & 41 & 100,0 \\
\hline
\end{tabular}

\section{Hubungan antara Tingkat Pengetahuan tentang Kusta dengan Kepatuhan Minum MDT}

Hasil analisis hubungan antara variabel independen tingkat pengetahuan responden tentang kusta dengan variabel dependen kepatuhan minum MDT di Puskesmas Kejayan dan Puskesmas Pohjentrek dapat dilihat pada Tabel 4 berikut.

Tabel 4. Kontigensi hubungan tingkat pengetahuan tentang kusta dengan kepatuhan minum MDT 


\begin{tabular}{ccccccccc}
\hline \multicolumn{4}{c}{ Kepatuhan minum MDT } & & \multicolumn{3}{c}{ Odds Ratio } \\
\hline Pengetahuan & Tidak Patuh & Patuh & Total & $\%$ & $\begin{array}{c}\text { 95\% Confidence } \\
\text { interval }\end{array}$ & P value \\
& N & $\%$ & N & $\%$ & & & OR $=6,667$ & 0,025 \\
Sedang & 9 & 22 & 3 & 7,3 & 12 & 29,3 & $1,451-30,64$ & \\
Tinggi & 9 & 22 & 20 & 48,8 & 29 & 70,7 & & \\
Total & 18 & 44 & 23 & 56 & 41 & 100 & & \\
\hline
\end{tabular}

Hasil uji chi square pada Tabel 4 terdapat nilai signifikansi $P$ value sebesar $0,025^{* *}(p<0,05)$ dengan hasil perhitungan chi square sebesar 6.667 yaitu lebih besar dari tabel $X^{2}$. Hal ini berarti bahwa $\mathrm{Ho}$ ditolak dan $\mathrm{H} 1$ diterima. Sementara untuk membandingkan antara tingkat pengetahuan terhadap kepatuhan minum MDT, berdasarkan nilai odds ratio sebesar 6,667 yang berarti bahwa tingkat pengetahuan sedang lebih banyak yang tidak patuh minum obat MDT, namun tingkat pengetahuan tinggi lebih banyak yang patuh minum obat MDT. Analisis data tersebut menunjukkan terdapat hubungan antara tingkat pengetahuan tentang kusta dengan kepatuhan minum MDT di Puskesmas Kejayan dan Puskesmas Pohjentrek Kabupaten Pasuruan. Arah hubungan antara dua variabel positif dan nilai kontigensinya termasuk dalam katagori agak rendah. ${ }^{11}$

\section{Pembahasan}

\section{Karakteristik Umum Responden}

Jumlah responden dalam penelitian ini adalah sebanyak 41 orang, yang meliputi 27 penderita kusta di wilayah kerja Puskesmas Kejayan dan 14 penderita kusta di wilayah kerja Puskesmas Pohjentrek Kabupaten Pasuruan. Hal ini bukan berarti sejumlah 41 penderita kusta saja yang terdaftar, tetapi fenomena yang terjadi pada penderita kusta seperti fenomena gunung es dalam artian bahwa jumlah penderita kusta yang belum ditemukan dan terdeteksi jauh lebih besar dari jumlah yang sudah ditemukan. Dalam penelitian kali ini peneliti hanya mengambil sampel penelitian berdasarkan kriteria inklusi dan ekslusi penderita kusta yang terdiagnosis kusta oleh Puskesmas Kejayan dan
Puskesmas Pohjentrek, yang sedang menjalankan pengobatan aktif serta penderita masa pengamatan.

\section{Tingkat Pengetahuan tentang Kusta}

Pengetahuan adalah hasil penginderaan manusia atau hasil tahu seseorang terhadap objek melalui indera yang dimilikinya. Dengan sendirinya pada waktu penginderaan sampai menghasilkan pengetahuan tersebut sangat dipengaruhi oleh intensitas perhatian dan persepsi terhadap objek. Sebagian besar pengetahuan seseorang diperoleh melalui indera pendengaran dan indera penglihatan. ${ }^{8}$

Berdasarkan penelitian yang telah dilakukan didapatkan mayoritas tingkat pengetahuan pasien kusta tentang pengobatan dalam tingkat yang baik/tinggi. Dari 41 responden, terdapat 29 responden $(70,7 \%)$ yang memiliki tingkat pengetahuan tinggi, 12 responden $(29,3 \%)$ memiliki tingkat pengetahuan sedang.

\section{Hubungan Usia Responden dengan Tingkat Pengetahuan tentang Kusta}

Data hasil penelitian menyebutkan bahwa karakteristik usia responden dibagi menjadi 2 yaitu usia paling muda 12 tahun dan paling tua yaitu 65 tahun. Peneliti juga mendapatkan beberapa penderita kusta berada dalam usia sekolah, sehingga perlu adanya perhatian khusus terhadap lingkungan sekolah untuk dilakukan penyuluhan tentang kusta karena lingkungan sekolah dengan anak didik usia remaja cenderung untuk kontak lebih erat dengan teman sebayanya. Usia adalah jumlah hari, bulan, tahun yang telah di lalui sejak lahir sampai dengan waktu tertentu. Usia juga bisa diartikan sebagai satuan waktu yang mengukur waktu keberadaan suatu benda atau 
makhluk, baik yang hidup maupun yang mati. Misalnya umur manusia dikatakan lima belas tahun diikuti sejak dia lahir hingga waktu umur itu dihitung. ${ }^{12}$

Individu yang berumur lebih dewasa cenderung proaktif dalam mengikuti program kesehatan karena faktor pengalaman dan bertambahnya usia. Hasil penelitian ini tidak didapatkan hubungan yang bermakna antara kelompok umur responden dengan tingkat pengetahuan pasien kusta tentang pengobatan, sehingga tidak sesuai dengan pendapat Notoatmodjo (2007) bahwa pengetahuan dipengaruhi oleh usia responden. ${ }^{9}$ Pada strategi peningkatan pengetahuan, individu yang lebih tua cenderung kurang dapat mengambil nilai lebih dari stimulus atau suatu materi yang diterimanya, walaupun stimulus itu tetap dapat diproses sesuai dengan objek yang diberikan untuk menghasilkan suatu pengetahuan, akan tetapi pengetahuan didapat dari pengalaman belajar individu itu sendiri. ${ }^{13}$

\section{Hubungan Jenis Kelamin dengan Tingkat Pengetahuan tentang Kusta}

Menurut Notoatmodjo (2007) jenis kelamin merupakan identitas responden yang dapat digunakan untuk membedakan pasien laki-laki atau perempuan. Hasil penelitian menunjukkan mayoritas jenis kelamin pasien kusta yang menjalani program terapi MDT di Puskesmas Kejayan dan Puskesmas Pohjentrek adalah laki-laki 26 orang $(63,4 \%)$, serta sebagian perempuan sebanyak 15 orang $(36,6 \%)$.

Hasil yang diperoleh dari uji statistik tidak didapatkan hubungan yang bermakna antara jenis kelamin dengan pengetahuan pasien kusta tentang pengobatan. Hal ini dapat terjadi karena sebagian besar laki-laki menghabiskan waktu hidupnya di luar rumah sehingga kemungkinan adanya pengaruh dari pengalaman yang di dapatkan dari lingkungan dari orang lain seperti tetangga, media informasi yang mereka dengar maupun lihat tentang program terapi MDT lebih mudah dapat di terima. ${ }^{9}$

\section{Hubungan Pendidikan dengan Tingkat Pengetahuan tentang Kusta \\ Pendidikan responden mayoritas} menengah (SLTP/MTS) sebanyak 19 orang $(46,3 \%)$, dan tingkat pengetahuan tentang kusta dalam tingkat yang tinggi 29 orang $(70,7 \%)$. Pendidikan seseorang merupakan salah satu proses perubahan tingkah laku, semakin tinggi pendidikan seseorang maka dalam memilih tempat pelayanan kesehatan semakin di perhitungkan. ${ }^{14}$

Hal ini menunjukkan bahwa penyakit kusta tidak hanya didominasi oleh pendidikan rendah, tetapi yang berpendididkan menengah ke atas mungkin juga untuk terserang penyakit kusta. Meskipun pendidikan formal yang diterima akan sangat berpengaruh terhadap pengetahuan yang dimiliki oleh responden, namun masih banyak faktor lain yang mempengaruhi pengetahuan seseorang terhadap penyakit kusta misalnya media cetak, media elektronik atau pengalaman, namun semuanya akan mempengaruhi terbentuknya sebuah tingkah laku. ${ }^{9}$

Dengan pendidikan yang baik maka pengetahuan dan penangkapan informasi akan baik pula. Pendidikan responden mayoritas menengah (SLTP/MTS) kurang memberikan kemudahan bagi pasien kusta dalam berkomunikasi dan menerima informasi terutama dalam bidang kesehatan. Dengan cara berfikir yang baik maka seseorang akan lebih cepat dalam mengambil keputusan dalam bidang kesehatan. Sebaliknya pendidikan yang kurang akan menghambat perkembangan sikap seseorang terhadap nilai baru yang diperkenalkan. ${ }^{10}$

\section{Hubungan Jenis Pekerjaan dengan Tingkat Pengetahuan tentang Kusta \\ Berdasarkan pekerjaan responden} dibedakan menjadi tidak memiliki pekerjaan, pekerjaan informal dan formal, diketahui bahwa sebagian besar responden memilki pekerjaan informal (wiraswasta) sebanyak 22 orang $(53,7 \%)$. dan sebanyak 19 orang $(46,3 \%)$ responden bekerja di sawah sebagai 
petani. Hal ini memungkinkan responden kontak aktif dengan banyak orang di masyarakat sehingga dapat menularkan penyakit kusta pada orang lain. Sesuai dengan pernyataan Suparman (1990), bahwa penyakit kusta sebagian besar menyerang kalangan ekonomi rendah. ${ }^{15}$

Hasil penelitian menunjukkan bahwa tidak terdapat hubungan yang bermakna antara pekerjaan dengan tingkat pengetahuan pasien kusta tentang pengobatan. Pembagian jenis pekerjaan ini menentukan tinggi rendahnya kebutuhan ilmu yang dapat membentuk pola kemampuan menyerap, mengolah dan memahami suatu informasi. Bekerja juga akan memudahkan seseorang untuk menjangkau informasi. Tetapi seperti dijelaskan bahwa kebutuhan akan ilmu (tingkat pengetahuan) dan sumber informasi tidak berhubungan dengan pekerjaan, maka pekerjaan formal yang membutuhkan pendidikan tinggi sehingga seseorang mudah mendapatkan sumber informasi

Hasil penelitoan juga menunjukkan bahwa sebanyak $70,7 \%$ responden memiliki tingkat pengetahuan tentang kusta dalam katagori tinggi. Sedangkan responden yang memiliki tingkat pengetahuan tentang kusta katagori sedang sebanyak $29,3 \%$. Tingkat pengetahuan tentang kusta dipengaruhi oleh beberapa hal, salah satu diantaranya adalah pendidikan formal. Faktor lain yang mempengaruhi pengetahuan responden adalah pengalaman. Pada responden kusta masa pengamatan memungkinkan mempunyai pengalaman yang cukup mengenai pengobatan kusta. Hal ini dikarenakan penderita kusta kronis lebih lama mengenal penyakit kusta, lebih lama mendapatkan informasi dari media cetak, media elektronika dan lebih sering melakukan kontak dengan petugas kesehatan.

Hal ini didukung oleh hasil penelitian terdahulu bahwa berbagai strategi telah dicoba untuk meningkatkan kepatuhan salah satunya yaitu dengan memberikan informasi yang jelas kepada penderita mengenai penyakit yang dideritanya serta cara pengobatannya. Sehingga fungsi mengingatpun berjalan dengan baik. Dengan penerimaan informasi yang baik penderita dapat memepertahankan informasi tersebut untuk diterapkan dalam kehidupan sehari-hari khususnya tentang pengobatan kusta. ${ }^{16}$

Hal ini juga didukung oleh Notoatmodjo (2007) yang mengatakan pengetahuan atau kognitif merupakan domain yang sangat penting untuk terbentuknya tindakan seseorang (overt behavior) karena dari pengalaman dan penelitian perilaku yang didasarkan oleh pengetahuan akan lebih langgeng daripada perilaku yang tidak didasari oleh pengetahuan. ${ }^{9}$

Sebelum orang mengadopsi perilaku baru (berperilaku baru), di dalam diri seseorang tersebut terjadi proses yang berurutan yaitu: awarenes (kesadaran), interest (merasa tertarik), evaluation (menimbang-nimbang), trial (mencoba), adoption (adopsi). Meskipun ada beberapa orang yang mengalami perubahan perilaku tanpa melewati tahaptahap tersebut. Namun apabila perubahan perilaku baru melewati semua tahapan di atas dengan didasari oleh pengetahuan, kesadaran dan sikap yang positif, maka perilaku tersebut akan bersifat langgeng (long lasting). Sebaliknya apabila perilaku itu tidak didasari oleh pengetahuan atau kesadaran akan tidak permanen.

\section{Hubungan Usia Responden dengan Kepatuhan Minum MDT}

Data hasil penelitian menyebutkan bahwa pasien kusta sebagian besar yang menjalani program terapi MDT berusia termuda 12 tahun dan tertua berumur 65 tahun, dan katagori patuh minum MDT sebanyak 23 orang $(56,1 \%)$. Akan tetapi pada uji statistik tidak ditemukan hubungan antara kelompok umur dengan kepatuhan minum MDT.

\section{Hubungan Jenis Kelamin dengan Kepatuhan Minum MDT}

Hasil penelitian menunjukkan bahwa sebagian besar pasien kusta yang menjalani program terapi MDT adalah laki-laki 26 orang 
$(63,4 \%)$. Hal ini kemungkinan terkait dengan laki-laki lebih banyak dipengaruhi oleh lingkungan teman dan aktivitasnya. Hasil uji statistik tidak ditemukan hubungan jenis kelamin dengan kepatuhan minum MDT. Hal ini karena penelitian dilakukan hanya pada satu tempat yang sama dan populasi yang ditemukan sebagian besar laki- laki.

\section{Hubungan Pendidikan dengan Kepatuhan Minum MDT}

Pada penelitian ini pendidikan responden sebagian besar menengah (SLTP/MTS) sebanyak 19 orang $(46,3 \%)$ dan yang memilki katagori patuh minum MDT yaitu 23 orang $(56,1 \%)$. Dari hasil uji statistik tidak terdapat hubungan yang bermakna antara pendidikan dengan kepatuhan minum MDT. Hal ini sesuai dengan pendapat Sunaryo (2004), pendidikan adalah mencakup seluruh proses kehidupan individu sejak dalam ayunan hingga liang lahat baik secara formal maupun informal. Proses dan kegiatan pada dasarnya melibatkan masalah perilaku individu maupun kelompok. Sehingga perlu adanya proses pelayanan dan pendekatan yang berbeda dalam menimbulkan motivasi pada setiap individu atau kelompok.

Makin tinggi pendidikan seseorang makin mudah menerima informasi sehingga menimbulkan kepatuhan dan dorongan yang tinggi untuk terlibat dalam program pengobatan atau kesehatan yang optimal. Kepatuhan yang timbul dari proses yang dipelajari akan menimbulkan sikap atau perilaku yang permanen atau bersifat terus menerus dan bertahan lama. ${ }^{9}$

\section{Hubungan Jenis Pekerjaan dengan Kepatuhan Minum MDT}

Hasil peneltian terhadap 41 orang responden tehadap jenis pekerjaan yang sebagian besar bekerja di bidang informal (wiraswasta) sebanyak 22 orang $(53,7 \%)$ serta memiliki katagori patuh yaitu sebanyak 23 orang $(56,1 \%)$. Pada penelitian ini tidak ditemukan hubungan korelasi bermakna antara karakteristik jenis pekerjaan dengan kepatuhan minum MDT. Hal ini tidak sesuai dengan teori yang menjelaskan pekerjaan adalah suatu kegiatan yang dilakukan untuk mendapatkan upah atau imbalan. Jika upah atau imbalan tinggi maka tingkat pekerjaan semakin berat dan repot sehingga berpengaruh pada motivasi seseorang. ${ }^{17}$

Pengetahuan berperan sebagai salah satu faktor internal yang mempengaruhi terbentuknya perilaku, selain juga dipengaruhi oleh faktor eksternal seperti dukungan dari tenaga kesehatan. Penderita kusta yang telah mendapatkan informasi tentang pengobatan kusta dari petugas kesehatan dan dapat menerima dengan baik akan cenderung berusaha melaksanakannya. Didukung pula oleh tenaga kesehatan yang melakukan kunjungan rumah secara berkala pada penderita kusta, sehingga dapat memantau penatalaksanan pengobatan kusta.

Adanya dukungan dari profesi kesehatan dapat mempengaruhi perilaku kepatuhan. Dukungan mereka terutama dalam perilaku hidup sehat. Mereka juga memepengaruhi perilaku pasien dengan cara menyampaikan antusias mereka terhadap tindakan tertentu dari pasien, dan secara terus menerus melalui pemberian penghargaan yang positif bagi pasien yang telah mampu beradaptasi dengan program pengobatan dan perawatannya. ${ }^{18}$

Interaksi profesional kesehatan dengan penderita kusta adalah suatu hal yang penting untuk memberikan umpan balik pada pasien setelah memberikan informasi tentang diagnosis. Penderita kusta membutuhkan penjelasan kondisinya, apa penyebabnya dan apa yang dapat mereka lakukan dengan kondisinya. Hal ini didukung oleh Safarino (1990), bahwa salah satu strategi untuk meningkatkan kepatuhan adalah memperbaiki komunikasi antara tenaga kesehatan dan penderita kusta. ${ }^{16}$ Berbagai komunikasi antara petugas kesehatan dan penderita kusta akan mempengaruhi kepatuhan, misalnya informasi dengan pengawasan yang baik, kepuasan aspek hubungan emosional, dan kepuasan terhadap pengobatan yang diberikan. Frekuensi pengawasan, dukungan atau 
tindakan lanjutan juga cukup penting untuk diperhatikan.

Faktor lain yang mempengaruhi kepatuhan adalah dukungan keluarga. Dukungan sosial dalam bentuk dukungan emosional dari anggota keluarga, teman, waktu dan finansial merupakan faktor-faktor penting dalam kepatuhan terhadap programprogram medis. Keluarga dan teman dapat membantu mengurangi ansietas yang disebabkan oleh penyakit tertentu, mereka dapat menghilangkan godaan pada ketidaktaatan dan mereka sering kali dapat menjadi kelompok pendukung untuk mencapai kepatuhan. ${ }^{18}$

Niven (2002) mengatakan bahwa derajat ketidakpatuhan bervariasi sesuai dengan apakah pengobatan tersebut kuratif, preventif, jangka pendek atau jangka panjang. Adanya kegagalan untuk mengikuti program pengobatan jangka panjang yang bukan dalam kondisi akut, dimana derajat ketidakpatuhannya rata-rata $50 \%$ dan derajat tersebut bertambah buruk sesuai waktu.

Salah satu faktor internal yang mempengaruhi ketidakpatuhan responden adalah pengetahuan. Meskipun pendidikan formal bukan satu-satunya sumber informasi untuk responden mempunyai pengetahuan yang baik, namun hal ini akan sangat mempengaruhi perilaku seseorang. Faktor internal lainnya yang mempengaruhi ketidakpatuhan adalah pengalaman terutama bagi penderita kusta baru. $\mathrm{Hal}$ ini memungkinkan penderita kusta baru belum paham mengenai pengobatan karena baru pertama kali menderita penyakit tersebut. Faktor eksternal lain yang mempengaruhi ketidakpatuhan adalah tingkat sosial ekonomi rendah. Fasilitas lingkungan rumah yang tidak mendukung kesehatan akan berpengaruh terhadap pengobatan kusta. Peneliti menemukan beberapa responden tinggal dalam rumah dengan kondisi lingkungan rumah yang tidak menunjang kesehatan. Rumah yang kurang ventilasi, lantai yang lembab dan kurang pencahayaan merupakan lingkungan fisik yang mendukung penyebaran penyakit kusta. ${ }^{19}$

Faktor sosial ekonomi yang rendah sangat berpengaruh terhadap pengobatan kusta karena memungkinkan kemampuan penderita kusta untuk memodifikasi lingkungan sangatlah kurang. Salah satu diantaranya adalah memenuhi kebutuhan gizi untuk menunjang pengobatan kusta. Keadaan ini sesuai dengan hasil penelitian bahwa penderita kusta tidak patuh dalam mengkonsumsi makanan tinggi protein dan memisahkan peralatan makan penderita kusta dengan anggota keluarga yang lainnya. Hal ini dapat dimungkinkan karena salah satunya adalah keadaan sosial ekonomi rendah yang didukung oleh karakteristik responden sebagian besar $(53,7 \%)$ bekerja di sektor swasta. Dengan sosial ekonomi yang rendah maka pemenuhan kebutuhan kesehatanpun tidak dapat terpenuhi dengan baik. $^{15}$

\section{Hubungan Tingkat Pengetahuan tentang Kusta dengan Kepatuhan Minum MDT}

Hasil penelitian menunjukkan bahwa terdapat hubungan yang bermakna antara variabel tingkat pengetahuan tentang kusta dengan variabel kepatuhan minum MDT dengan koefisien kontigensi sebesar OR = 6,667 dan signifikansi sebesar $0,025^{* *}(p<$ 0,05 ) yang berarti keeratan hubungan dua variabel dalam katagori agak rendah. ${ }^{11}$

Pengetahuan akan program terapi MDT dapat diperoleh dari pengalaman pribadi dalam kehidupan sehari-harinya. Dengan pengalaman ini pengetahuan pasien kusta menjadi meningkat, yang menjadi dasar pembentukan sikap dan dapat mendorong perilaku kepatuhan mereka untuk selalu datang dan menjalankan program terapi MDT. ${ }^{17}$ Hubungan antara dua variabel ini sesuai dengan apa yang dikatakan oleh Notoatmodjo (2007) bahwa pengetahuan sangat penting dalam terbentuknya sebuah perilaku. Perilaku dimulai dari stimulus yang diterima oleh akal yang merupakan respon atau reaksi seseorang terhadap stimulus dari 
luar. Selanjutnya manusia membayangkan stimulus tersebut sehingga manusia dapat mengadakan pilihan atau seleksi terhadap berbagai alternatif dalam lingkungannya untuk mencapai efektifitas yang optimal dalam mempertahankan hidupnya.

Hal ini menunjukkan bahwa perilaku yang didasarkan pada pengetahuan akan lebih permanen dan bermanfaat bagi kehidupan individu yang akan dating. ${ }^{9}$ Individu akan mengulangi perilaku yang dianggap efektif untuk mengatasi masalah yang sama. Dalam epidemiologi penyakit menular pengetahuan berperan sebagai faktor risiko dari penularan penyakit kusta sehingga hal ini sangat perlu untuk diperhatikan.

Berdasarkan analisis di atas menunjukkan bahwa tingkat pengetahuan yang tinggi akan membentuk perilaku kesehatan yang baik sehingga resiko penyebaran penyakit kusta semakin berkurang. Meskipun pengetahuan yang tinggi tidak selalu dimiliki oleh penderita yang berpendidikan menengah keatas, karena informasi merupakan stimulus dari luar yang tidak hanya didapatkan dari pendidikan formal tetapi bisa didapatkan dari penyuluhan, media masa, media elektronik ataupun pengalaman yang akan tampak dalam perilaku individu tersebut. ${ }^{9}$

\section{Keterbatasan Penelitian}

Keterbatasan yang dihadapi oleh peneliti adalah instrumen yang digunakan dalam penelitian ini merupakan kuesioner yang dibuat sendiri oleh peneliti, Pengambilan data dengan kuisioner bersifat sangat subjektif sehingga kebenaran data sangat tergantung pada kejujuran responden dan pertanyaan bersifat tertutup sehingga kurang dapat menggali permasalahan yang ada pada diri setiap responden. Pada observasi kepatuhan untuk mengetahui ketepatan dan kepatuhan terapi tidak dapat dilakukan selama 24 jam penuh, dengan demikian kemungkinan ada manipulasi perilaku penderita pada saat pelaksanaan terapi. Observasi dengan melihat sekali waktu dalam periode tertentu tidak bisa mengambarkan kepatuhan secara utuh terhadap pasien. Peneliti tidak mampu mengikuti perilaku kepatuhan pasien kusta dalam kurun waktu selama 3 bulan, tetapi karena terbatasnya waktu yang tersedia, peneliti hanya melakukan observasi selama 3 bulan, yang seharusnya selama 12 bulan.

\section{Kesimpulan}

Kesimpulan dari penelitian ini diketahui bahwa tingkat pengetahuan responden tentang kusta adalah dalam katagori tinggi yaitu 29 orang $(70,7 \%)$. Kepatuhan responden terhadap minum sebagian besar adalah dalam katagori patuh yaitu 23 responden $(56,1 \%)$. Terdapat hubungan yang bermakna $\left(p=0,025^{* *} ; p<\right.$ $0,05)$ antara tingkat pengetahuan tentang kusta dengan kepatuhan minum MDT pada pasien kusta di Puskesmas Kejayan dan Puskesmas Pohjentrek Kabupaten Pasuruan. Jadi, semakin tinggi tingkat pengetahuan tentang kusta maka akan semakin patuh minum MDT $(O R=6,667)$.

\section{Saran}

\section{Untuk Peneliti Selanjutnya}

1) Diharapkan ada penelitian lanjutan untuk mengetahui faktor lain yang lebih mempengaruhi kepatuhan minum MDT, seperti faktor dukungan keluarga dan dukungan petugas kesehatan.

2) Dengan keterbatasan penelitian diharapakan kepada peneliti selanjutnya tidak hanya dengan menggunakan instrumen berupa kuesioner sehingga teknik pengambilan data lebih akurat dan hasilnya lebih sempurna di masa yang akan datang.

\section{Untuk Instansi Terkait}

1) Diharapkan hasil penelitian dapat digunakan sebagai sumber informasi yang dapat meningkatkan kualitas pelayanan dan pemberantasan penyakit kusta. 
2) Diharapkan petugas kusta Puskesmas yang terlibat dapat mengoptimalkan waktu penemuan dini dan pelayanan yang intensif serta merubah stigma negatif bagi petugas kesehatan dan masyarakat untuk mendukung dan berperan serta aktif khususnya di bidang penyuluhan kesehatan yaitu program terapi MDT bagi pasien kusta secara efektif dan berkesinambungan.

3) Diharapkan petugas kusta Puskesmas mencari faktor penyebab ketidakpatuhan minum MDT dengan mengontrol pengambilan obat paket MDT setiap bulan, mengawasi penuh keteraturan minum obat MDT setiap hari dengan bantuan keluarga, kunjungan rumah secara berkala ke penderita kusta, penanganan pasien kusta tulus sepenuh hati tidak memarahi/membentak terhadap pasien yang tidak patuh minum obat MDT.

\section{Untuk Instansi Pendidkan}

1) Diharapkan penelitian ini dapat digunakan sebagai dasar untuk mengembangkan ilmu dan pendidikan keperawatan serta mencegah atau merawat penyakit kusta dan dampak buruk yang ditimbulkannya.

2) Diperlukan adanya pengembangan dan inovasi baru dari ilmu kesehatan khususnya keperawatan komunitas yang dapat meningkatkan kepatuhan minum MDT dan keteraturan pasien kusta untuk menjalankan program terapi serta perubahan stigma negatif dari masyarakat, serta mendorong program terapi MDT sebagai program terapi pilihan utama pengobatan pasien kusta.

\section{Daftar Pustaka}

1. Amirudin. IImu Penyakit Kulit. Cetakan I. Jakarta: Penerbit Hipokrates. 2005.

2. Haeria. Pengembangan Sistem Informasi Program Kusta Berbasis Geografis di
Kabupaten Cirebon Tahun 2005. Jurnal Kesehatan Masyarakat Nasional. 2005; I(2).

3. Kandun N. Manual Pemberantasan Penyakit Menular. Jakarta: Dirjen P2M \& PL. 2007.

4. Chin J. Manual Pemberantasan Penyakit Menular. I Nyoman Kandun (Penerjemah). Jakarta: Ditjen PPM \& PLP. 2000.

5. Dinas Kesehatan Propinsi Jawa Timur. Profil Kesehatan Propinsi Jawa Timur Tahun 2009. Surabaya. 2009.

6. Departemen Kesehatan RI. Buku Pedoman Nasional Pengendalian Penyakit Kusta. Dirjen Pengendalian Penyakit dan Penyehatan Lingkungan. Jakarta: Depkes RI. 2007.

7. Nukman. Psikologi untuk Keperawatan. Jakarta: EGC. 1997.

8. Hashmi. Faktor-Faktor yang Berhubungan dengan Ketidakteraturan Berobat Penderita Kusta di Kabupaten Majalengka Tahun 1998-2000. Tesis. Jakarta: Program Pasca Sarjana Fakultas Kesehatan Masyarakat UI. 2007.

9. Notoatmodjo S. Metodologi Penelitian Kesehatan. Edisi Revisi ke-1. Jakarta: Penerbit Rineka Cipta. 2007.

10. Nursalam. 2009. Konsep dan Penerapan Metodologi Penelitian IImu Keperawatan, Pedoman Skripsi, Tesis, dan Instrumen Penelitian Keperawatan. Edisi ke-2. Jakarta: Salemba Medika.

11. Arikunto S. Prosedur Penelitian suatu Pendekatan Praktik. Jakarta: Penerbit Rineka Cipta. 2006.

12. Hurlock BE. Psikologi Perkembangan. Edisi Ke-5. Jakarta: Penerbit Erlangga. 1993.

13. Irwanto. 2010. Psikologi Umum. Jakarta. PT.Gramedia Pustaka Utama

14. Azwar S. Sikap Manusia, Teori dan Pengukurannya. Edisi Ke-2. Jakarta: Penerbit Pustaka Pelajar. 2007. 
15. Suparman. Penderita Kusta di Indonesia Harus Sembuh Total pada 2005. (Online).

1990.http://www.Gizi.Net/cgibin/berita/full news.Cgi?Newsid1082349328.7519985.

Diakses 17-5-2012.

16. Smet B. Psikologi Kesehatan. Jakarta: Grasindo. 1994.

17. Purwanto N. Psikologi Pendidikan. Bandung: Remaja Rosdakarya. 2010.

18. Niven N. Psikologi Kesehatan: Pengantar untuk Perawat dan Profesional Kesehatan Lain. Jakarta: EGC. 2002.

19. Noor. Penyakit Kusta dan Masalah yang Ditimbulkannya. Medan: Fakultas Kesehatan Masyarakat USU. 1997. 